\title{
ARCTIC NORWAY WITH THE ROYAL MARINES
}

\author{
Major P. C. C. PITT, F.R.C.S., M.R.C.P., R.A.M.C. \\ British Military Hospital, H.Q., British Gurkha L of C, Dharan
}

IN the Winter of 1965, 500 Royal Marines learned to survive and fight in arctic conditions and finally took part in a N.A.T.O. exercise.

On 24th February, 1965 we flew to Bardufoss Airport, some 100 miles inside the Arctic Circle and then travelled about an hour's journey (depending on who drove!) north east to the Garrison of Skjold. The distance is about 40 miles, and the "road" reminded me of the Cresta Run, being practically a solid sheet of ice with banked-up ice walls. Sticks were placed every six feet to mark the area which the snow ploughs had to clear, to break up the monotony of driving and to differentiate the road from the banks. I was pleasantly surprised to find that we were housed in the Norwegian Officers' Mess, in cabins just big enough to take two beds, with tremendously efficient central heating, hot showers, sauna baths and a small swimming pool.

The Royal Marines were quite fearless on the feather weight skis or "planks" as they called them. They climbed the highest hills and skied straight down from the first day onwards. Turning and stopping were arts they had yet to learn. $I$ have never seen such sickening and spectacular crashes, yet the injury rate was fantastically low. Some nights were bitterly cold and the temperature once fell to minus $45^{\circ} \mathrm{C}$. Fortunately there was very little wind, so that conditions were bearable and we were so energetic that we hardly used the parkas provided, and skied happily in our combat suits.

Life was not all skiing; we learnt camouflage in the snow, all about snow weasels and the thrilling art of ski-joring. A long rope was attached to the back of the weasel and some ten men attached themselves to this at about five yard intervals, by winding the rope round the handles of their ski-sticks and putting the ends of these under their arms (Fig. 1). We practised on a frozen lake in various formations-almost as exciting as water skiing. The marines were pretty good after about an hour's practice. A few miles further north the Lapps have ski-joring races behind reindeer under similar conditions.

During these first three weeks of our five-week exercise the marines spent a few nights out in the snow. Our first night was in a M39 tent (Fig. 2)-built for 16 men, the tent "pole" being the pipe of a stove which we all took turns to feed with logs of wood-and which I succeeded in making red hot in my hour, much to the anxiety of the Norwegian officer who did the next watch! Our next night was spent under tent sheets-we were each issued with one of these which could be buttoned together to make a tent of any size. We slept in a seven man tent and dug a hole in the snow making a snow bank all the way round the tent site. The floor was an 18 inch deep layer of birch twigs with reindeer skins on top. There is no shortage of wood--silver birches and Christmas trees are everywhere. We were very comfortable and warm in our sleeping bags which were very efficient, having an inner layer and an outer waterproof covering. It was essential to put our boots in the sleeping bags with us as otherwise they would have frozen solid. Next day the ground looked like a battlefield where the uncured reindeer skins had touched the snow. These skins cost the Army 10 Kroner (10 shillings) uncured, but up to $£ 10$ to $£ 15$ for a well-cured skin. Ours were so uncured that lumps of meat were still attached and this led to cryptic comments about supplementing the 


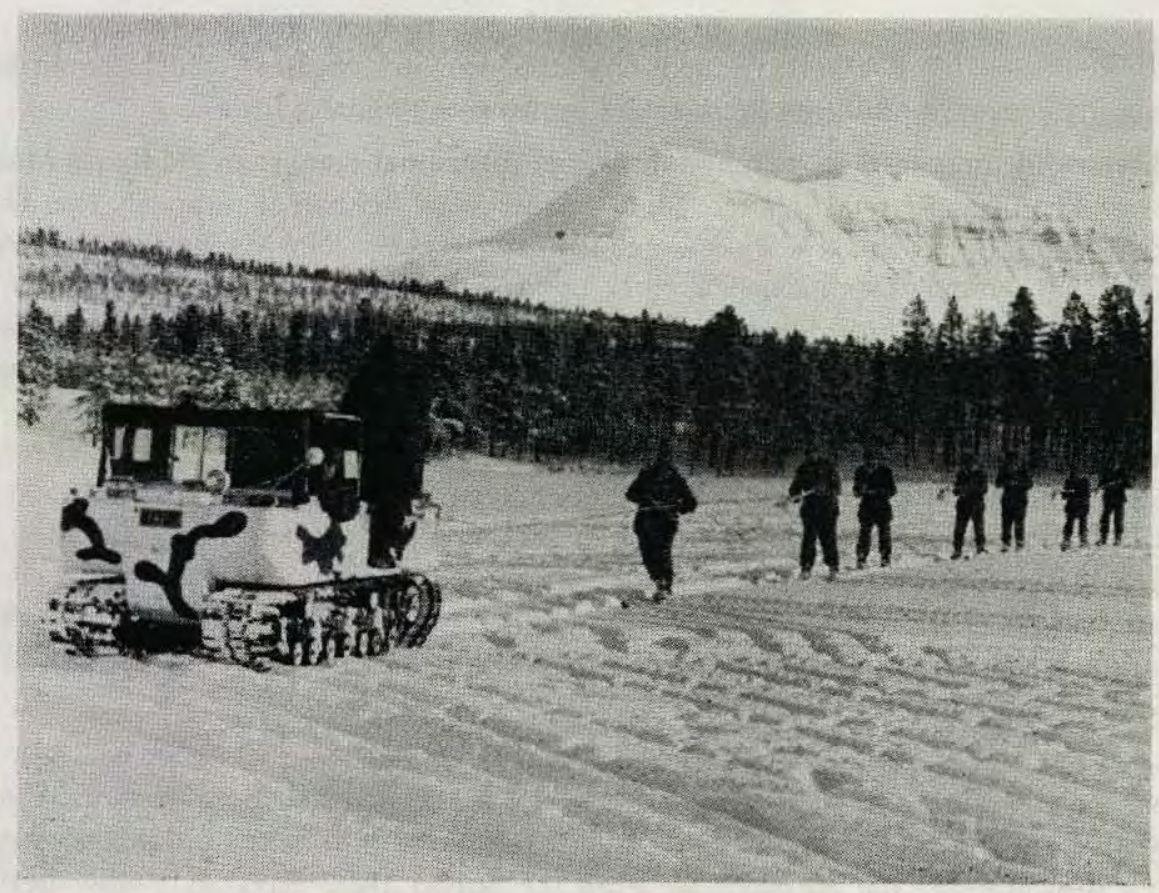

Fig. 1. Marines learning ski-joring across a frozen lake pulled by a snow weasel.

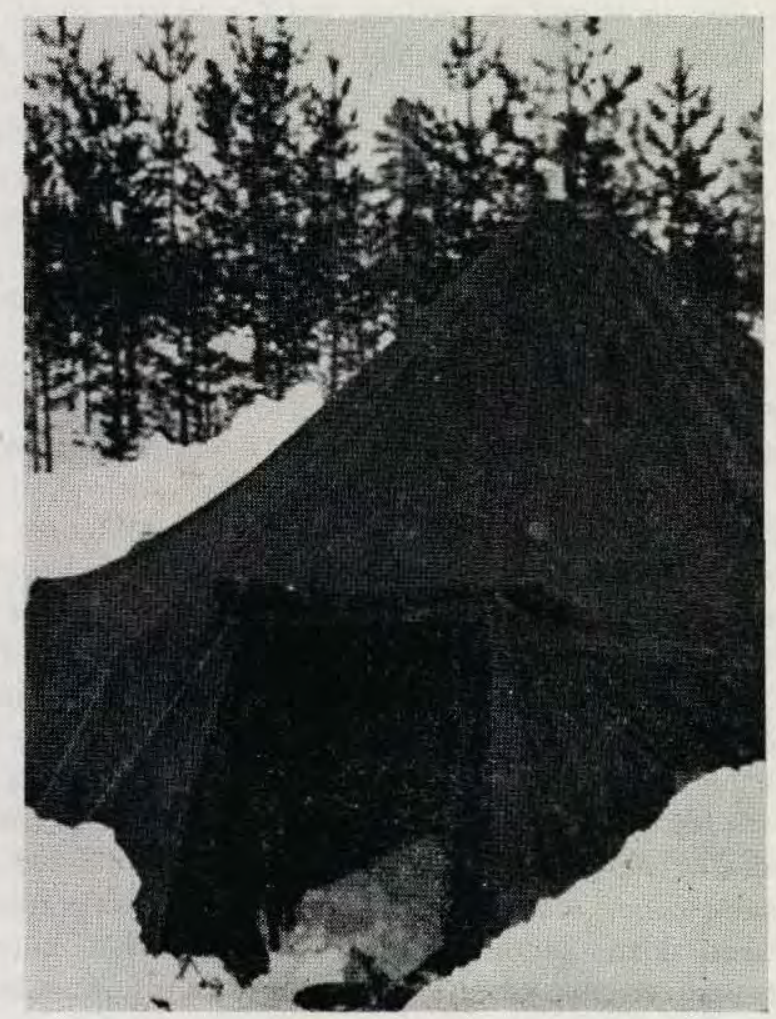


Norwegian diet (cold meats, tinned fish and various cheeses) which comments I thoroughly endorsed-still the exercise did improve my figure a little!

Meanwhile preparations were in full swing for the final exercise of the Royal Marines, a Royal Artillery Battery, United States Army plus helicopter support, the United States Marines and a small Norwegian contingent, versus a Norwegian force about two thirds of our combined strength. The Norwegians quite liked these exercises, as they were paid " overtime" when on schemes. Sweden would not allow the 17 huge helicopters to fly over any of her territory-we believed she was determined not to let this incident affect her neutrality with Russia-this meant either a 60-odd-mile sea crossing from Denmark to Norway, or dismantling the helicopters. I asked a pilot which he preferred and he left no doubt in my mind. Helicopters had to be dismantled and crated and each packed inside a Globemaster. I watched this fascinating work being done for the return journey at the Bardufoss airport while we were waiting eight frustrating hours for an Argosy to take us home and was amazed at the speed and efficiency with which this operation was performed. Air support was further provided by Hunter and Sabre fighters.

The eight-day exercise started with the Royal Marines attacking from the North to make the exercise more authentic for the Norwegians. It had been expected that the Russians would monitor radio messages but this proved not to be so, and the Norwegians told us how friendly the Russians were on the border these days, and how they now sometimes even drank vodka together, whereas a few years ago they would have pointed guns at each other. The Norwegian packhorses were beautiful and were used for pulling the heavy guns in deep snow and up inclines that the weasels could not manage. The Norwegians built excellent igloo-type stables for the horses who wore snow shoes like gigantic lower ends of ski-sticks. The poor brutes still stumbled however, but I was assured by the Norwegian officers that they were quite happy-for by now the temperature was much warmer, although sudden blizzards did occur. Several tents collapsed one night and had to be re-assembled in a bitter blizzard. The Royal Marines did brilliantlymaking up for their poor downhill skiing technique by early--very early-rising and personal fitness, taking their " enemies" by surprise and enhancing their own reputation in decisively winning this war against both them and the cold.

Of interest medically, about 20 cases of mild frost bite were reported-noses, ears, fingers and toes, all but two recovering in minutes, hours or days. We warmed up the frozen parts with our hands, or in water at about $37^{\circ} \mathrm{C}$, with good results. One man wore the ordinary army woollen gloves instead of the special double knits provided by the Norwegians for this exercise, and got them wet and therefore frozen at minus $30^{\circ} \mathrm{C}$; he lost most of the skin of one finger, which is still very stiff. Another man did not take the precaution of putting his boots in his sleeping bag and put on frozen boots with wet socks, losing tissue from his big toes. Prophylaxis was most important. All ranks were instructed to watch each others' faces and I was stopped by the guard at the gate to the camp when my nose had gone completely white after skiing at minus $26^{\circ} \mathrm{C}$. Patting the nose was recommended and was efficient, and putting frozen hands in one's axillae worked well. The marines soon learned this, so few had to report to our medical centre. My personal experience of frost bite worried me considerably as I am a comparatively experienced skier and therefore travelled down hill much faster than the marines. This increased velocity decreases skin temperature substantially. The cold was 
so intense that I did not realise that I had frost bite even though I was constantly aware of the danger. As the marines became more proficient skiers they would themselves be far more liable to frost bite and yet less aware of this danger than I was as a doctor.

We had the usual typical skiing injuries-torn and strained medial ligaments of knee, lateral ligaments of ankle, sprained groin muscles. We were interested in the $7: 1$ predominance of injuries on the left side. In the upper limbs, sprained first metacarpophalangeal joints and bruised olecranon processes were common. We had only five fractured bones: neck of humerus, lateral malleolus, olecranon process, Bennett's fracture and radial styloid-so were able to return in the same numbers as we came out, but the poor Quartermaster had to deal with the problem of 80 broken Pairs of skisan incredibly high injury rate, to which I regret I added.

\section{Queen's Honorary Physician}

Major-General James Alexander Deans Johnston, O.B.E., M.C., M.B., has been appointed Honorary Physician to the Queen in succession to Major-General M. H. P. Sayers, O.B.E., M.D., retired.

\section{Royal College of Surgeons of England}

Colonel S. H. Janikoun, O.B.E., F.R.C.S., Royal Army Medical College, has been admitted to the Chair of Military Surgery held jointly with the Royal College of Surgeons of England.

\section{British Society of the History of Medicine}

Dr. William Sydney Charles Copeman, O.B.E., T.D., has been elected President of the British Society of the History of Medicine in succession to Dr. Douglas Guthrie.

Dr. Copeman served as an Ensign with the Coldstream Guards in the First World War and as a Lieutenant-Colonel in the Royal Army Medical Corps in the Second World War, one of his appointments being Adviser in Medicine, Malta Command in 1943. He was mentioned in despatches twice.

At present he is a trustee of the Royal Army Medical Corps Historical Museum.

\section{Sergeant-Surgeon to the Queen}

Sir Ralph Marnham, K.C.V.O., M.A., M.Chir., F.R.C.S., has been appointed Sergeant-Surgeon to the Queen in succession to Sir Authur Porritt.

Sir Ralph served in the Royal Army Medical Corps in the Second World War, appointments held including those of Officer in Charge of Surgical Divisions of No 62 and 6 General Hospitals, and Consulting Surgeon to the 9th Army, East Africa and Southern Commands. He was mentioned in despatches twice. 